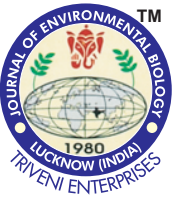

\title{
An integrated approach for evaluation of groundwater quality in Korba district, Chhattisgarh using Geomatic techniques
}

\section{Authors Info}

S. Singha ${ }^{1 *}$, S. Pasupuleti', S. Singha ${ }^{1}$ and V. G. K. Villuri ${ }^{2}$ 'Department of Civil Engineering, Indian Institute of Technology (Indian School of Mines), Dhanbad-826 004, India 'Department of Mining Engineering, Indian Institute of Technology (Indian School of Mines), Dhanbad-826 004, India

*Corresponding Author Email : sssingha077@gmail.com

Key words

Groundwater quality, Physico-chemical parameters IDW method, Potable water, Geomatic techniques, Ground Water quality index

\section{Publication Info}

Paper received : 24.02.2017

Revised received : 16.05 .2017

Re-revised received : 30.05.2017

Accepted: 31.05.2017

\section{Abstract}

Aim: The objective of the study was to evaluate and assess present groundwater quality scenario by developing groundwater quality index map for Korba district in Chhattisgarh.

Methodology: For the study, well wise water quality data was collected for 719 villages over the period of six years from 2009 to 2015 .The relative weights, quality rating scale and accordingly weighted values were calculated to estimate the overall groundwater quality index (GQI) and calculation of GQI was carried out for 10 parameters such as $\mathrm{pH}$, turbidity, total hardness, chloride, calcium, nitrate, iron, magnesium, sulphate and fluoride. GQI map was developed by creating spatial reference to point locations for which the quality of groundwater is known using GIS software.

Results: The concentration of the parameters in the study area was found in the following order: Turbidity $>$ Iron $>\mathrm{pH}>$ Fluoride $>$ Nitrate $>$ Magnesium $>$ Calcium $>$ Chloride > Total Hardness > Sulphate. Groundwater quality index map show decrease in water quality from north to east in the study area. According to the classification of GQI, $8.86 \%$ of water sampling locations were found having GQI less than 100 means bearing good quality water and $91.14 \%$ having GQI greater than100 indicating non potable water.

Interpretation: Application of GQI in the present work communicates comparative information on groundwater quality of Korba district. Presence of low water quality in the study area may be attributed due to mining activities and overexploitation of groundwater. Analysis suggests that groundwater in the study area needs specific treatment before supply to the public as potable water.

\section{Evaluation of groundwater quality in Korba district}

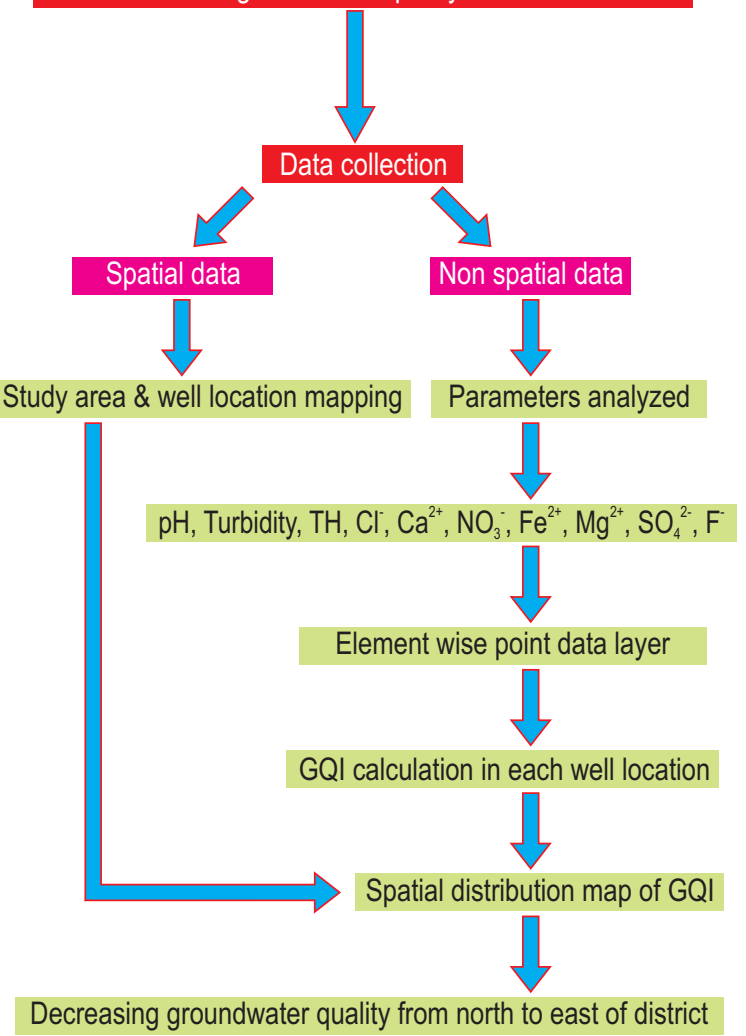




\section{Introduction}

Earth is known as "The Blue Planet" because of its massive oceans and other water bodies, which is unique in universe for its quality of living organisms and water is essential for existence of living organisms. Water pollution simultaneously affects the water quality and threats the economic development and social prosperity of human health (AI-Rajab and Hakami, 2014). On earth, water is available as surface water and groundwater. Major part of the population from urban and rural areas depends on subsurface water. Subsurface water is one of the essential and valuable natural resource, which not only supports the life on the earth but governs the agricultural, industrial, economical and social growth of human beings, however due to population growth, urbanization and industrialization, the demand for groundwater is potentially increasing day by day, which imposes pressure on groundwater resources and leads to higher concentration of elements.

Groundwater quality deterioration of a specific area depends on a large number of individual hydrological, physical, geochemical and biological factors (llavarasan et al., 2016). Generally higher proportions of dissolved constituents are found in groundwater compared to surface water because of greater interaction of groundwater with various materials in geologic strata. In addition, inferior water quality may also be observed in a region due to continuous abstraction of shallow fresh groundwater (Islam et al., 2014). This may be due to percolation of chemicals from land surface, confining aquifers or adjacent aquifers that contain polluted or saline water. A wide range of measured variables associated with contamination sources is among the factors contributing to the complexity of groundwater quality assessment and monitoring (Srivastava et al., 2009).

In order to integrate water quality variables, water quality index have been developed which transform large quantity of water quality data into a single number and express as a single term (Shiji et al., 2016). By determining of Water Quality Index (WQI), suitability of groundwater and surface water samples for the purpose of human consumption can be assessed (Ravikumar etal., 2013).

In developing countries like India around $80 \%$ of water borne diseases can be attributed to poor drinking water quality and unhygienic conditions (Balakrishnan et al., 2011). Scientific efforts has been taken to address the problem of water quality in India led by Rajiv Gandhi National Drinking Water Mission (RGNDWM) with external agencies like United Nations Children's Fund (UNICEF). As assessment of groundwater quality was not given due importance, water borne diseases have become common now a days. In environmental quality management related to potable water, paramount importance is given to water quality (Sundara Kumar et al., 2010). In India, various groundwater research works of similar nature have been carried out to identify potential sites for groundwater assessment and management (Remesan and Panda, 2007). GIS mainly handles the layer wise existing geographical features, capable to analyze and represents the computational multimap integrations (Subramani et al., 2012). GIS plays a vital role in assessing the water quality status as well as the solutions towards water quality related issues (Shankar et al., 2010). Several aspects which contribute the drinking water crisis are rapidly increasing trend of population, industrial needs, unnecessary over exploitation of groundwater, change of land use pattern, environmental hot-spot etc (Shomar et al., 2010).

The focused research was an attempt to map the quality of groundwater of Korba district in Chhattisgarh by creating spatial reference to point locations for which the quality of groundwater is known using GIS. The study also aimed to calculate GQI and develop GQI map for better understanding of the groundwater quality scenario in the study area.

\section{Materials and Methods}

Study area: Korba district was selected as the study area, which is one of the well known districts for the major coal production areas in Chhattisgarh, as well as in Central India. The total area of open cast coal mines is about $530 \mathrm{sq}$. km within the district. In most of the open cast mines, coal excavation is carried out more than hundred meters below from the ground surface, resulting in huge groundwater deterioration in the area. The study area is shown in Fig. 1a, which is located in the east-central part of Chhattisgarh. It comprises of total 719 villages under five blocks namely Korba, Katghora, Kartala, Pali and Podi-Upraro are shown in Fig. 1a. River Hasdeo flows north to south throughout its length in the district and eventually joins the Mahanadi River (Fig.1a). Geologically, Korba district is underlain mainly by three distinct geological formations ranging in age from Achaean to Recent. The geology map of the study area is shown in Fig. $1 \mathrm{~b}$. From geological point of view, Korba district can be categorized into three groups such as Chhota Nagpur Gneissic Complex, Chhattisgarh Super Group of rocks, Gondwana Super Group of rocks with various formations. According to the formations, study area is divided into 22 parts (Fig.1b). The granite and granitic gneiss rocks of Chhota Nagpur Group, occupy western and south-western parts of the study area (Fig.1b). Phyllite and quartzite has limited occurrence towards the southern part and western, south-western part of the district, respectively (Fig.1b). The rocks of Chhattisgarh Super Group overlying the basement crystalline are represented by the sandstone, limestone and shale sequence occupying small area at the southern part of the region (Fig.1b). The rocks of Gondwana Super Group constitute the major part of the district and is represented by sandstone, shale and coal seams with various combinations (Fig.1b). Ferruginous sandstone with carbonaceous shale and very thin coal seams of Kamthi formation forms prominent ridges in the eastern part of the district (Fig.1b). The basalts occur as narrow 


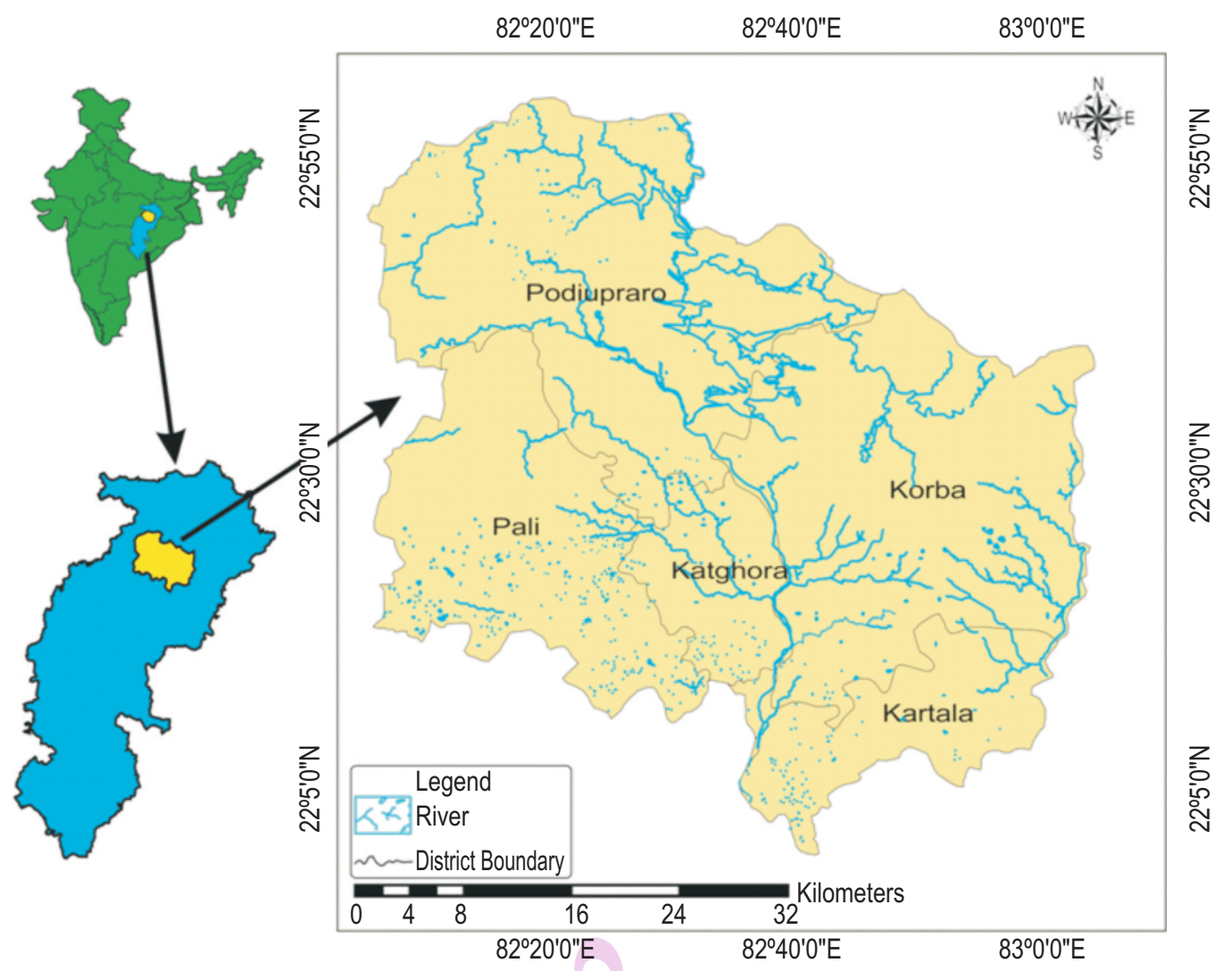

Fig. 1(a) : Location map of study area

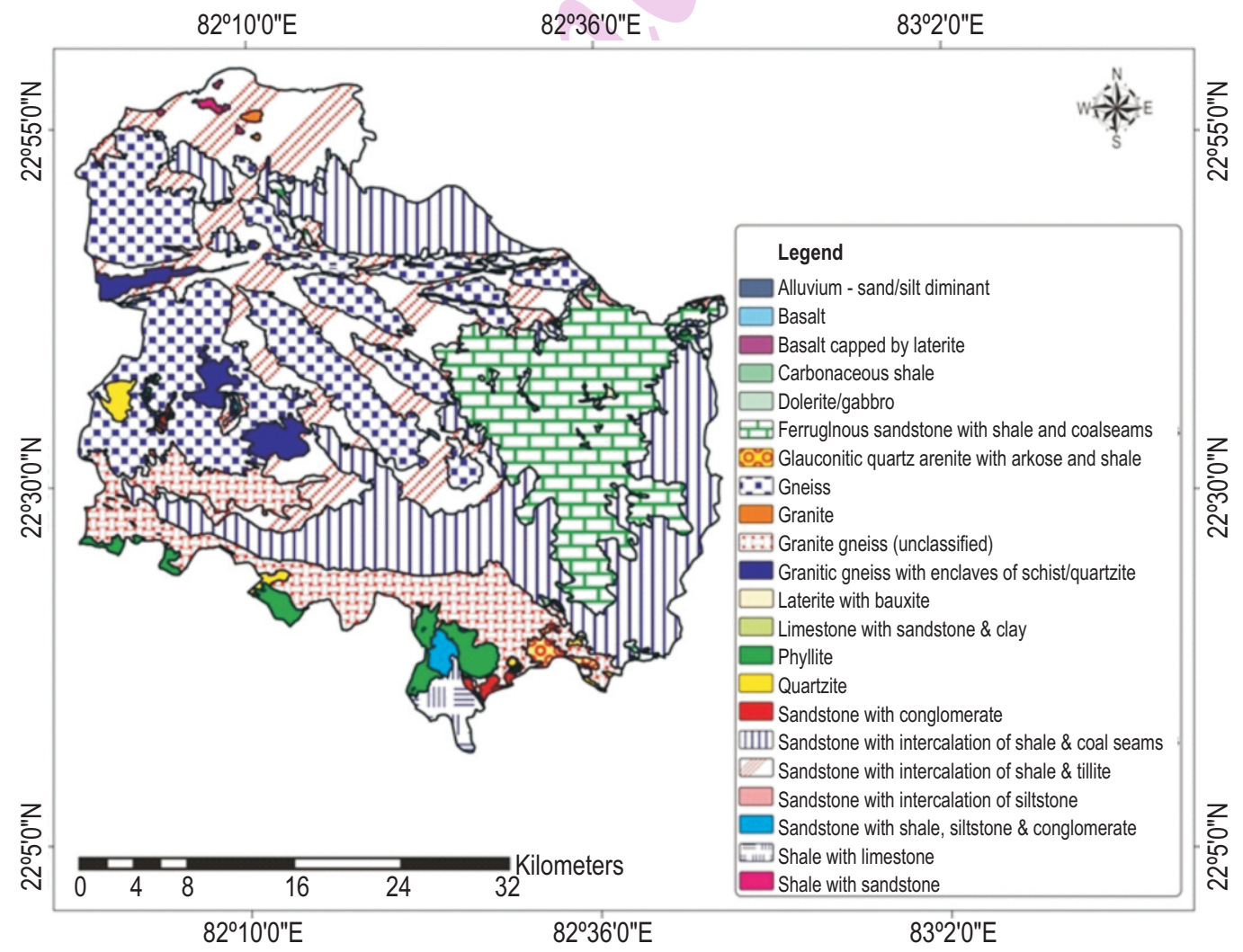

Fig. 1 (b) : Geology map of study area (source CGCOST, Raipur) 
linear ridges in the northern part of the district (Fig.1b). Few laterite capings with small lenses of bauxite occur in the eastcentral and west-central part of the area over Barakar and Kamthi sandstone (Fig.1b). The pre-monsoon groundwater level varies from 3.18 to 13.47 meter below ground level $(\mathrm{mbgl})$ with average water level of $8.3 \mathrm{mbgl}$ and the post-monsoon water level varies from 0.81 to $10.21 \mathrm{mbgl}$ with average water level of $4.5 \mathrm{mbgl}$ according to Central Groundwater Board (CGWB). The yield in granitic rocks varies from 0.5 to $3.5 \mathrm{lps}$. The yield in sedimentary formation varies from 0.28 to $7.1 \mathrm{Ips}$ (Source: Groundwater Brochure of Korba District, Chhattisgarh, 2012).

Data source and processing : In the present study, topographical maps (64J $05,06,07,10,11,14,15 \& 16)$ of Survey of India (SOI) on 1:50,000 scale, IRS LISS III digital data Path 102, 103 Row 56 was used. GIS software was used for database creation and generation of thematic layers for various parameters. Groundwater quality data was collected for 719 villages from CGCOST, Raipur over a period of 6 years from 2009 to 2015 . Attribute database for the present study was prepared in GIS by taking the mean value of each parameter. Ten groundwater quality parameters namely $\mathrm{pH}$, turbidity, total hardness, calcium, magnesium, sulphate, iron, fluoride, nitrate, chloride were selected for determining of GQI. Weighted Arithmetic index method was used for determining of GQI (Cude, 2001).

Data interpolation : For obtaining the spatial distribution of above mentioned groundwater quality parameters, Inverse Distance Weighting (IDW) method was used to interpolate data points. Using these techniques, element wise groundwater quality thematic maps of Korba district was predicted for unknown locations for each parameter. The entire element wise groundwater parameter layers $(\mathrm{pH}$, turbidity, total hardness, calcium, magnesium, sulphate, iron, fluoride, nitrate, chloride) were integrated using GIS software. As a result of integration a combined groundwater quality layer (GQI map) was generated.

\section{Results and Discussion}

Chemical contaminants may provoke various health issues such as trouble in breathing, dermatitis, methemoglobinemia, etc. (WHO, 2015). Table 1 shows the summary of physico-chemical parameters with their ranges as per BIS standards and total area contaminated or not contaminated. The $\mathrm{pH}$ value is less than 6.5 which covers an area of $159.56 \mathrm{sq} . \mathrm{km}$ and $\mathrm{pH}$ value more than 6.5 which covers an area of $6985.88 \mathrm{sq}$. $\mathrm{km}$ (Table 1) of the study area. Low pH concentration was observed in the study area may be due to acid mine drainage (AMD) or spill of acidic materials from the industries. AMD is a waste product of the mining as well as mineral industries which carries highly polluted water because of low $\mathrm{pH}$, dissolved heavy metals and sulphate (Kumari et al., 2010). pH of potable water is not a health related issue; however, since low acidic nature of water can leach metals from plumbing systems can cause health problems (Rahmanian et al., 2015).

Turbidity value was less than 5 NTU which covers $1380.08 \mathrm{sq} . \mathrm{km}$ and major part of the area $5765.36 \mathrm{sq} . \mathrm{km}$ (Table 1) having turbid water (more than 5 NTU). Higher concentration of turbidity observed may be due to anthropogenic impact on groundwater. Armah et al. (2010) highlighted the issue of contamination of groundwater in Tarkwa gold mining area at Ghana, due to anthropogenic activities and the need to mitigate the risks associated with humans drinking it. Turbidity of water less than $5 \mathrm{NTU}$ is acceptable for human consumption (WHO, 2012). Highly turbid water (greater than 5 NTU) may indicate the presence of pathogens (Rahmanian et al., 2015).

Major part of the study area showed total hardness concentration to be within the desirable limit as per BIS guidelines (IS: 10500:1991). An area of $7141.55 \mathrm{sq}$. km was found to have total hardness concentration less than $300 \mathrm{mg} \mathrm{l}^{-1}$ and $3.89 \mathrm{sq} . \mathrm{km}$ (Table 1) having more than $300 \mathrm{mg} \mathrm{r}^{-1}$, respectively. Calcium and magnesium contents are responsible for the hardness of water (Prasanth et al., 2012). Calcium concentration values less than 75 $\mathrm{mg} \mathrm{l}^{-1}$ covered $192.48 \mathrm{sq} . \mathrm{km}$ (Table 1), whereas an area of $6940.67 \mathrm{sq}$. km (Table 1) was found to have calcium concentration ranging between $75-200 \mathrm{mg} \mathrm{l}^{-1}$ (within the permissible limit) and 12.29 sq. km (Table 1) area having calcium concentration more than $200 \mathrm{mgl}^{-1}$ (above the permissible limit). Similarly magnesium

Table 1 : Summary of physico-chemical parameters and areal extent of contamination

\begin{tabular}{lll}
\hline Parameter & Range & Area cover (in sq.km) \\
\hline $\mathrm{pH}$ & $<6.5$ & 159.56 \\
& $>6.5$ & 6985.88 \\
Turbidity & $<5$ & 1380.08 \\
Total hardness & $>5$ & 5765.36 \\
& $<300$ & 7141.55 \\
Calcium & $>300$ & 3.89 \\
& $<75$ & 192.48 \\
& $75-200$ & 6940.67 \\
Magnesium & $>200$ & 12.29 \\
& $<30$ & 13.97 \\
Sulphate & $30-100$ & 7118.10 \\
Iron & $>100$ & 13.37 \\
& $<200$ & 7145.44 \\
Fluoride & $<0.3$ & 471.79 \\
& $0.3-1.0$ & 4410.96 \\
Nitrate & $>1.0$ & 2262.69 \\
Chloride & 1.0 & 6889.77 \\
& $>1.5$ & 172.76 \\
& $>45$ & 82.91 \\
& $>45$ & 7118.63 \\
& $>250$ & 26.81 \\
& $>250$ & 7133.51 \\
& & 11.93 \\
\hline
\end{tabular}


Table 2: The percentage of areal extent of GQI

\begin{tabular}{llll}
\hline Status & Scores & Area cover (in sq. km) & Percentage $(\%)$ of area covered \\
\hline Excellent & $0-50$ & 3.91 & 0.06 \\
Good & $51-100$ & 629.45 & 8.80 \\
Poor & $101-200$ & 3133.15 & 43.85 \\
Very Poor & $201-300$ & 1793.63 & 25.10 \\
Unfit for Drinking & $>301$ & 1585.30 & 22.19 \\
\hline
\end{tabular}

concentration less than $30 \mathrm{mgl}^{-1}$ was observed in an area of 13.97 sq. km (Table 1), an area of $7118.10 \mathrm{sq} . \mathrm{km}$ (Table 1) was found to be within the permissible limit $\left(30-100 \mathrm{mg} \mathrm{l}^{-1}\right)$ where as $13.37 \mathrm{sq}$. $\mathrm{km}$ (Table 1) area showed magnesium concentration above permissible limit (more than $100 \mathrm{mg} \mathrm{l}^{-1}$ ). Prasanth et al. (2012) reported that the higher calcium content may cause abdominal ailments and is not suitable for domestic purposes as it causes scaling and encrustation. Similarly intake of low calcium content increases risks of osteoporosis, nephrolithiasis, colorectal cancer, hypertension and stroke, coronary artery disease, insulin resistance and obesity (WHO, 2009). Moderate to high concentration of magnesium (10-100 $\left.\mathrm{mg} \mathrm{I}^{-1}\right)$ in drinking water potentially prevents 4.5 million heart disease and stroke deaths yearly, worldwide (Rosanoff, 2013). Deficiency or inadequate intake of magnesium increases risk of developing pathological problems to humans such as vasoconstrictions, hypertension, cardiac arrhythmia, atherosclerotic vascular disease, acute myocardial infarction, and eclampsia in pregnant women, possibly diabetes mellitus of type II and osteoporosis (Saris et al., 2000). Sulphate content in the entire study area (7145.44 sq. km) was observed within the desirable limit i.e. less than $200 \mathrm{mg} \mathrm{l}^{-1}$ (Table 1).

The study area was mostly influenced by iron concentration. An area of 471.79 sq. km (Table 1) was observed having iron concentration less than $0.3 \mathrm{mg} \mathrm{l}^{-1}$ (within desirable limit), $4410.96 \mathrm{sq} . \mathrm{km}$ (Table 1) area comes within the permissible limit of 0.3-1.0 mg l-1, where $2262.69 \mathrm{sq} . \mathrm{km}$ (Table 1) area was highly affected by iron concentration with more than $1.0 \mathrm{mg} \mathrm{l}^{-1}$ (above permissible limit). Presence of high iron concentration in the study area may be due to iron rich minerals in formation, AMD or corroded water distribution pipes. Ezeigbo and Ezeanyim (1993) reported that high iron content in groundwater was generally found due to the presence of large amount of pyrites in ground strata. Prasad et al. (2014) reported that the common forms of iron in nature are iron oxides which promote growth of "Iron bacteria" within iron pipes of water distribution systems. Grazuleviciene et al. (2009) reported presence of iron content in high doses in drinking water may cause neurological effects and long term iron toxicity may lead to progressive dysfunction and damage DNA.

One of the major influencing parameter in drinking water is fluoride concentration. An area of $6889.77 \mathrm{sq}$. km (Table 1) comes under potable water (less than $1.0 \mathrm{mg} \mathrm{l}^{-1}$ ), $172.76 \mathrm{sq} . \mathrm{km}$ (Table 1) area come within the permissible limit of $1.0-1.5 \mathrm{mg} \mathrm{l}^{-1}$, whereas $82.91 \mathrm{sq} . \mathrm{km}$ (Table 1) area was exposed to fluoride concentration higher than $1.5 \mathrm{mg} \mathrm{l}^{-1}$ (above permissible limit). The fluoride concentration observed in the study area may be due to the presence of fluoride rich minerals in the formations and anthropogenic activities. Fordyce et al. (2007) reported that high fluoride concentration in the environment might be due to various man made activities such as coal and aluminum industries, use of fertilizer and manufacturing process. Mondal et al. (2016) reported fluoride concentration above $1.5 \mathrm{mg} \mathrm{l}^{-1}$ carry an increasing risk of dental and skeletal fluorosis, as well as osteoporosis disease in women.

Nitrate concentration with less than $45 \mathrm{mg} \mathrm{l}^{-1}$ covered an area of $7118.63 \mathrm{sq} . \mathrm{km}$ (Table 1), where as nitrate concentration with values greater than $45 \mathrm{mg} \mathrm{l}^{-1}$ extended over an area of 26.81 sq. km (Table 1) in the study area. Elevated nitrate levels in the study area might be due to agricultural activities, inadequate manure management practices and open dump sites of solid wastes. Nitrate consumption may lead to methemoglobinemia in infants popularly called as "Blue Baby" syndrome (Min et al., 2002).

Chloride concentration with less than $250 \mathrm{mg} \mathrm{l}^{-1}$ i.e. within desirable limit extended over an area of $7133.51 \mathrm{sq} . \mathrm{km}$ (Table 1), where as $11.93 \mathrm{sq} . \mathrm{km}$ (Table 1) was observed having chloride concentration more than $250 \mathrm{mg} \mathrm{l}^{-1}$ in the study area. High chloride content may be due to disposal of wastes from industries and leaching of saline residues in the soil. The elevated levels of chloride content in groundwater is marked as an index of contamination and considered as tracer for groundwater pollution (Prasanth etal., 2012)

The concentration of the parameters in the study area was found in the following descending order: Turbidity $>\mid$ ron $>\mathrm{pH}$ $>$ Fluoride $>$ Nitrate $>$ Magnesium $>$ Calcium $>$ Chloride $>$ Total Hardness $>$ Sulphate.

Ten parameters viz., pH, turbidity, total hardness, calcium, magnesium, sulphate, iron, fluoride, nitrate and chloride were considered for the calculation of GQI. Application of GQI in the present work communicates comparative information on groundwater quality of Korba district. The percentage of areal extent of GQl is given in Table 2. Very few locations were having 


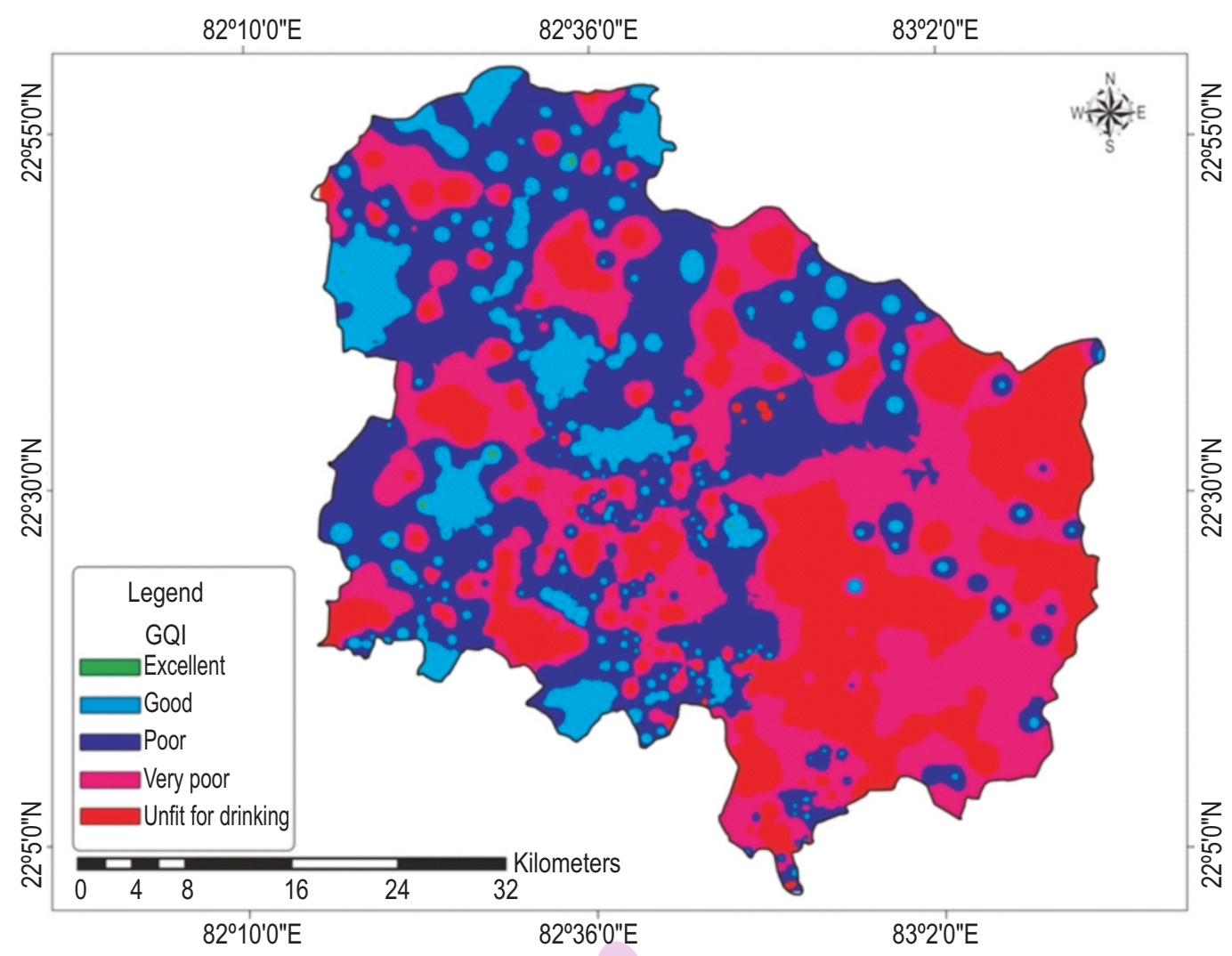

Fig. 2 (a) : Groundwater Quality Index (GQI) Map

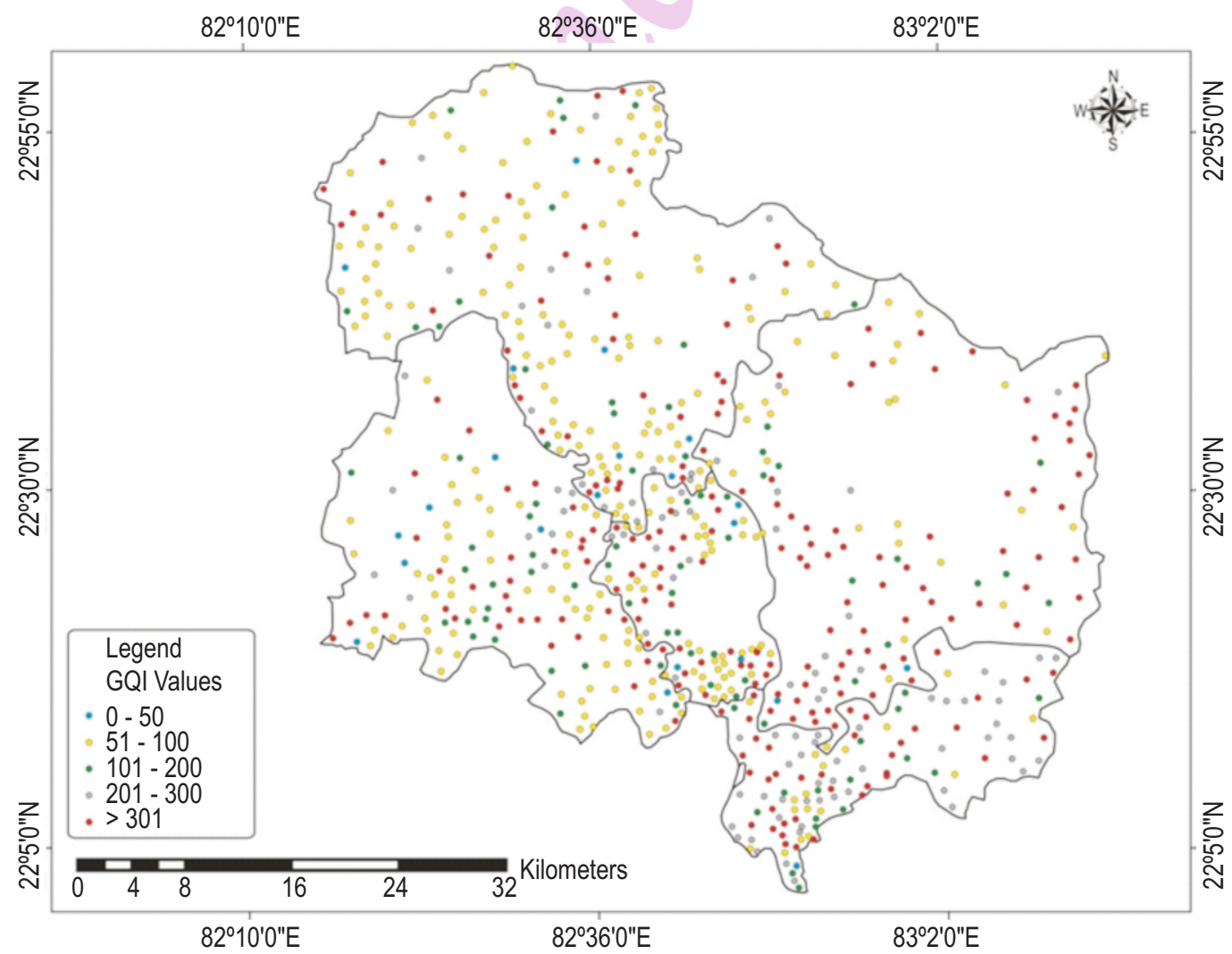

Fig. 2 (b) : GQI values for different wells 
excellent (0-50) quality of water (3.91 sq. km i.e. $0.06 \%$ ) (Table 2) in the study area. Locations having good (51-100) quality of water covered $629.45 \mathrm{sq}$. km (8.80\%) (Table 2) area, while poor (101200) and very poor (201-300) quality of water covered an area of 3133.15 sq. $\mathrm{km}(43.85 \%$ ) and $1793.63 \mathrm{sq} . \mathrm{km}(25.10 \%)$ (Table 2), respectively. Total area of $1585.30 \mathrm{sq} . \mathrm{km}(22.19 \%)$ (Table 2) comes under unfit for drinking (> 301) category. Armah et al. (2010) reported the groundwater samples from all sampling stations had WQI >100 in Tarkwa gold mining area, Ghana and can therefore be considered as unsuitable for human consumption without prior treatment which can be comparable to the present study i.e. GQI > 100 (91.14\%) (Table 2). The GQI map of the study area is shown in Fig. 2a. It is divided into five classes such as Excellent, Good, Poor, Very poor, and Unfit for drinking (Fig. 2a). The Groundwater Quality Index map (Fig. 2a) show a decrease in water quality from north to east in the study area. From GIS overlay analysis, it is inferred that quality of groundwater predominantly is of good quality, except in eastern locations (Fig. 2a). Heavy mining activities and agricultural practices in this region may be responsible for the contamination of groundwater. The major contaminated area of the study area belongs to Ferruginous Sandstone with shale and coal seams from Kamthi formation and Sandstone with intercalation of shale and coal seam from Barakar formation of Gondwana Super Group (source: Groundwater Brochure of Korba District, Chhattisgarh, 2012).

The well wise GQI values of the study area is shown in Fig. 2b. The GQI values assigned ranged from 0-50, 51-100, 101200, 201-300 and greater than 301 (>301) (Fig. 2b), respectively. For most of the locations, the GQI values were above 100 (Fig. $2 b)$ indicating non potable water. The permissible drinking water limit considered for the study is 100 (Sunil Kumar and Ravindranath, 1998). Ramakrishnaiah et al. (2009) recorded WQI of almost 700 in a mining area in Tumkur, India which were significantly high than that reported in the present study. The higher GQI values in the study area may be attributed due to the continuous discharge of industrial effluent, acid mine drainage from mining activities and agricultural practices.

It may be concluded that mining activities, agricultural practices and industrial effluents discharged in the study area contributes for low water quality, hence necessary steps may be taken to improve the water quality in the study area. Stringent rules should be imposed on mining activities and concern regulating authorities should monitor and prevent acid mine discharge to contaminate the valuable surface and groundwater resources.

\section{Acknowledgments}

The authors would like to acknowledge CGCOST and CGWB, Raipur for providing valuable data for the research work. The authors would like to extend their sincere thanks to the authorities of NIT, Raipur and IIT (ISM), Dhanbad for their technical support and for the facilities provided during the period of research work.

\section{References}

AI-Rajab, A.J. and O.M. Hakami: Behavior of the non-selective herbicide glyphosate in agricultural soil. Amer. J. Environ. Sci., 10, 94-101 (2014).

Armah, F.A., S. Obiri, D.O. Yawson, A.N.M. Pappoe and B. Akoto: Mining and heavy metal pollution: Assessment of aquatic environments in Tarkwa (Ghana) using multivariate statistical analysis. J. Environ. Stati., 1, 1-13(2010).

Balakrishnan, P., A. Saleem and N.D. Mallikarjun: Groundwater quality mapping using geographic information system (GIS): A case study of Gulbarga city, Karnataka, India. Afri. J. Environ. Sci. Technol., 5, 1069-1084 (2011).

Bureau of Indian Standard (BIS): Drinking water specifications, IS 10500 (1991).

CGWB: Central Groundwater Board, Groundwater Brochure of Korba District, Chhattisgarh, 1-14 (2012).

Cude, C.: Oregon water quality index: A tool for evaluating water quality management effectiveness. J. Amer. Water Resour. Associ., 37, 125-13 (2001).

Ezeigbo, H.I. and B.N. Ezeanyim: Environmental pollution from coal mining activities in the Enuga area, Anambka state, Nigeria. Mine WaterEnviron., 12, 53-62 (1993).

Fordyce, F.M., K. Vrana, E. Zhovinsky, V. Povoroznuk., G. Toth and B.C. Hope:Ahealth risk assessment for fluoride in Central Europe, Environ. Geochem. Hith., 29, 83-102 (2007).

Grazuleviciene, R., R. Nadisauskiene, J. Buinauskiene and T. Grazulevicius: Effects of elevated levels of manganese and iron in drinking water on birth outcomes. Polish J. Environ. Stud., 18, 819825 (2009).

llavarasan, N., R. Ilangovan and P.R. Prasanna: Water quality assessment on Ooty Lake in Nilgiris district. J. Environ. Biol., 37, 1463-1472 (2016).

Islam, M.J., M.A. Hakim, M.M. Hanafi, A.S. Juraimi, S. Aktar, A. Siddiqa, A.K.M. Shajedur Rahman, M.A. Islam and M.A. Halim: Hydrogeochemical quality and suitability studies of groundwater in northern Bangladesh. J. Environ. Biol., 35, 765-779 (2014).

Kumari, S., G. Udayabhanu and B. Prasad: Studies on environmental impact of acid mine drainage generation and its treatment: an appraisal. Ind. J. Environ. Protec., 30, 953-967 (2010).

Min, J.H., S.T. Yun, K. Kim, H.S. Kim, J. Hahn and K.S. Lee: Nitrate contamination of alluvial groundwaters in the Nakdong River basin, Korea. Geosciences J., 6, 35-46 (2002).

Mondal, D., G. Dutta and S. Gupta: Inferring the fluoride hydrogeochemistry and effect of consuming fluoridecontaminated drinking water on human health in some endemic areas of Birbhum district, West Bengal. Environ Geochem. Hlth., 38,557 (2016).

Prasad, B., P. Kumari, S. Bano and S. Kumari: Groundwater quality evaluation near mining area and development of heavy metal pollution index. Appl. Water Sci., 4, 11-17 (2014).

Prasanth, S., V. Sarath., N.S. Magesh, K.V. Jitheshlal, N. Chandrasekar andK. Gangadhar: Evaluation of groundwater quality and its suitability for drinking and agricultural use in the coastal stretch of Alappuzha District, Kerala. India Appl. Water Sci., 2, 165-175 
(2012).

Rahmanian, N., S.H.B. Ali, M. Homayoonfard, N.J. Ali, M. Rehan, Y. Sadef and A.S. Nizami: Analysis of physiochemical parameters to evaluate the drinking water quality in the state of Perak, Malaysia. J. Chem., Article ID-716125 (2015).

Ramakrishnaiah, C.R., C. Sadashivaiah and G. Ranganna: Assessment of Water Quality Index for the Groundwater in Tumkur Taluk, India. E-J. Chem., 6, 523-530 (2009).

Ravikumar, P., M.A. Mehmood and R.K. Somashekhar: Water quality index to determine the surface water quality of Sankeytank and Mallathahallilake, Banglore urban district, Karnataka, India. Appl. Water Sci., 3, 247-261 (2013).

Remesan, R. and R.K. Panda: Groundwater quality mapping using GIS: Astudy from India's Kapgari watershed. Environ. Qual. Manag., 16, 41-60 (2007).

Rosanoff, A.: The high heart health value of drinking-water magnesium. Med. Hypothe., 81, 1063-1065 (2013).

Saris, N.E.L., E. Mervaala, H. Karppanen, J.A. Khawaja and A. Lewenstam: Magnesium:An update on physiological, clinical and analytical aspects. Clin. Chim. Acta., 294, 1-26 (2000).

Shankar, K., S. Aravindan and Rajendran: GIS based groundwater quality mapping in Paravanar River sub basin, Tamil Nadu, India. Inter. J. Geom. Geosci., 1, 282-296 (2010).

Shiji, M., A.R. Sabitha, K. Prabhakar and P.S. Harikumar :Water quality assessment of Kavvayi Lake of northern Kerala, India using
CCME water quality index and biological water quality criteria. J. Environ. Biol., 37, 1265-1272 (2016).

Shomar, B., S. Fakher and A. Yahya: Assessment of groundwater quality in the Gaza strip, Palestine using GIS mapping. J. Water Res. Protec., 2, 93-104(2010).

Srivastava, N., G.H. Harit and R. Srivastava: A study of physico-chemical characteristics of lakes around Jaipur, India. J. Environ. Biol., 30, 889-894 (2009).

Subramani, T., S. Krishnan and P.K. Kumaresan: Study of groundwater quality with GIS application for Coonoor Taluk in Nilgiri district. Int. J. Mod. Engg. Res., 2, 586-592 (2012).

Sundara Kumar, K., P.S. Kumar., M.J. Ratnakanth Babu and C.H. Hanumanther Rao:Assessment and mapping of groundwater quality using geographical information systems. Inter. J. Eng. Sci. Technol., 2, 6035-6046 (2010).

Sunil Kumar, M. and S. Ravindranath: Water studies: Methods for monitoring water quality. Centre for Environmental Education, Bangalore (1998).

World Health Organization (WHO): Calcium and Magnesium in drinkingwater: public health significance, Geneva (2009).

World Health Organization (WHO): Guidelines for Drinking-Water Quality, 4th ed.; Geneva, Switzerland (2012).

World Health Organization (WHO): Burden of diseases and costeffectiveness estimates. Retrieved $9^{\text {th }}$ May 2015 from http://www. who.int/water_sanitation_health/diseases/burden/en/ (2015). 